\title{
Isolasi Bakteri Penghasil Biosurfaktan Menggunakan Media yang Mengandung Pestisida Karbosulfan
}

\section{Isolation of Biosurfactant-Producing Bacteria Using Medium Containing Carbosulfan Pesticide}

\author{
Frans Grovy Naibaho ${ }^{1}$, Nunuk Priyani ${ }^{2}$, Erman Munir $^{2}$, Nina Septania Damanik ${ }^{3}$ \\ ${ }^{1}$ Program Studi Biologi, Fakultas Matematika dan Ilmu Pengetahuan Alam, Universitas Palangka Raya \\ ${ }^{2}$ Departemen Biologi, Fakultas Matematika dan Ilmu Pengetahuan Alam, Universitas Sumatera Utara \\ ${ }^{3}$ Balai Karantina Pertanian Kelas I, Jayapura \\ Alamatemail: fransgrovy@mipa.upr.ac.id
}

\begin{abstract}
Abstrak - Penggunaan pestisida sintetik yang tidak terkontrol dapat menyebabkan pencemaran lingkungan karena meningggalkan senyawa pestisida di tanah dan perairan. Bioremediasi adalah salah satu cara untuk mengurangi cemaran senyawa kimia berbahaya di lingkungan dengan menggunakan mikroorganisme. Tujuan penelitian ini ialah untuk memperoleh isolat bakteri potensial penghasil biosurfaktan dari laut Belawan Sumatera Utara dan untuk mengetahui aktivitas biosurfaktannya. Isolasi bakteri dilakukan dengan menggunakan media selektif Bushnell-Hass Agar (BHA) yang mengandung 12 ppm pestisida berbahan aktif karbosulfan sebagai sumber karbon. Aktivitas biosurfaktan dilakukan dengan metode Drop collapsing test dan konsentrasi biosurfaktan dilakukan dengan metose orsinol yang dimodifikasi. Hasil penelitian menunjukkan 9 isolat berhasil diisolasi dan mampu tumbuh pada media yang mengandung karbosulfan. Aktivitas biosurfaktan tertinggi dihasilkan oleh isolat FB6 yang ditandai dengan pembentukan emulsi sebesar 5,627 mL dan produksi biosurfaktan tertinggi ditunjukkan oleh isolat FB7 dengan konsentrasi 54,6 ppm.
\end{abstract}

Kata kunci: bioremediasi, biosurfaktan, karbosulfan, pestisida

\begin{abstract}
Uncontrol uses of synthetic pesticide cause environmental pollution and leaves its residue in soil and water. Bioremediation is a way to reduce the contamination of harmful chemical compounds in the environment by using bacteria. The aim of this study were to obtain potential bacteria isolates which produce biosurfactant from Belawan sea, North Sumatera and to know their biosurfactant activity. Bacteria were isolated by using selective media Bushnell-Hass Agar (BHA) contain 12 ppm carbosulfan pesticide as carbon source. Biosurfactant activity was carried out with Drop collapsing test method and biosurfactant concentration was carried out with modified orsinol method. The result showed 9 isolate were able to grow on mediun containg carbosulfan pesticide. The highest biosurfactant activity was produced by FB6 isolate which characterized by the formation of emulsion of $5.627 \mathrm{~mL}$ and the highest biosurfactant production was shown by FB7 isolates with concentration of 54.6 ppm.
\end{abstract}

Keywords: bioremediation, biosurfactant, carbosulfan, pesticide.

(C) 2020 Jurnal Jejaring Matematika dan Sains. This work is licensed under a CC BY-NC 4.0

\section{PENDAHULUAN}

Pengendalian hama penyakit tanaman dengan menggunakan pestisida dianggap cara yang cepat dalam mengurangi gangguan hama dan penyakit tanaman, namun penggunaan pestisida yang intensif dapat menjadi masalah karena meninggalkan residu pada tanaman dan mencemari lingkungan yaitu tanah, permukaan maupun air tanah [1].

Residu pestisida yang mencemari lingkungan pada umumnya adalah senyawa hidrokarbon. Pestisida ini sulit terurai dan bersifat toksik bagi mahluk hidup. Pestisida dengan bahan aktif karbosulfan merupakan pestisida dengan senyawa hidrokarbon kompleks yang memiliki satu cincin aromatik pada struktur kimianya. Karbosulfan merupakan pestisida golongan karbamat yang bersifat toksik dan sulit terdegradasi [2]. Oleh karena itu, senyawa ini harus diuraikan agar tidak menimbulkan dampak kerusakan lingkungan yang semakin.

Salah satu metode efektif dan aman bagi lingkungan untuk mendegradasi senyawa pencemar adalah dengan teknik bioremediasi. Bioremediasi adalah proses perbaikan dan pemulihan kondisi lingkungan yang telah rusak akibat senyawa kimia pencemar dengan bantuan mikroorganisme khususnya bakteri [3]. Mikroorganisme merupakan bioremediator yang mampu mengurangi bahkan menghilangkan senyawa cemaran pestisida dengan beberapa mekanisme yaitu: adsorbsi, reaksi reduksi dan reaksi oksidasi [4]. Mikrob yang dapat digunakan dalam mengurai senyawa hidrokarbon aromatik adalah mikrob yang menghasilkan biosurfaktan. Mikrob dengan produksi biosurfaktan tinggi pada umumnya mempunyai kemampuan yang tinggi juga dalam menguraikan senyawa hidrokarbon aromatik [5]. 
Biosurfaktan adalah senyawa aktif permukaan yang di ekskresikan oleh mikrob ketika tumbuh pada medium yang mengandung substrat yang tidak larut dalam air. Senyawa ini memiliki gugus hidrofilik dan hidrofobik. Kedua gugus ini dapat menurunkan tegangan permukaan suatu cairan. Molekul tersebut berikatan satu sama lain dengan baik sehingga senyawa ini mampu menyatukan permukaan antar cairan yang berbeda polaritas seperti air dan hidrokarbon [6].

Bakteri penghasil biosurfaktan banyak ditemukan pada daerah yang tercemar senyawa hidrokarbon aromatik [7]. Bakteri yang diisolasi dari daerah tumpahan minyak telah dilaporkan memiliki kemampuan menghasilkan biosurfaktan dan mampu mendegradasi senyawa hidokarbon aromatik polisiklik seperti pirena [4]. Bakteri penghasil biosurfaktan juga mampu mengurangi kadar pestisida glifosat secara in vitro [8]. Penelitian ini bertujuan untuk mengisolasi dan mengkarakterisasi bakteri penghasil biosurfaktan dalam media tumbuh yang mengandung pestisida karbosulfan serta mengetahui aktivitas biosurfaktan yang dihasilkan.

\section{METODE PENELITIAN}

\section{A. Isolasi dan Karakterisasi Koloni Bakteri Penghasil Biosurfaktan}

Sampel air laut yang tercemar minyak diambil dari Dermaga Pelabuhan Ujung Baru Belawan dengan menggunakan botol winkler steril. Bakteri penghasil biosurfaktan diisolasi dengan menggunakan media Bushnel Hass Agar (BHA) yang mengandung 12 ppm karbosulfan. Sebanyak $0,1 \mathrm{ml}$ sampel air laut diinokulasikan ke dalam media BHA yang mengandung 12 ppm karbosulfan kemudian diinkubasi pada suhu $30^{\circ} \mathrm{C}$ selama 10-15 hari agar pertumbuhannya bakteri yang tumbuh maksimal. Koloni yang tumbuh pada media BHA dimurnikan pada media Tryptone Soya Agar (TSA) dan dikarakterisasi morfologi koloni, bentuk sel, pewarnaan Gram dan sifat biokimianya yang terdiri dari uji sitrat, uji gelatin, katalase katalase, uji TSIA, dan uji amilase.

\section{B. Aktivitas Biosurfaktan}

Aktivitas biosurfaktan dilakukan dengan metode Drop Collapsing Test yang dimodifikasi [9], [10], metode ini bertujuan untuk mengetahui penurunan tegangan permukaan cairan ditandai dengan terbentuknya emulsi. Masing-masing isolat bakteri diinkubasi dalam media Bushnell Hass Broth (BHB) selama 14 hari pada kondisi gelap. Kultur bakteri kemudian disentrifugasi dengan kecepatan $6000 \mathrm{rpm}$ selama 10 menit. Sebanyak $4 \mathrm{ml}$ supernatan dicampur dengan $4 \mathrm{ml} \mathrm{n}$-heksana dan $2 \mathrm{ml}$ akuades. Campuran tersebut divorteks selama 10 detik kemudian didiamkan selama satu menit. Emulsi yang terbentuk diamati dan diukur volumenya.

\section{Produksi Biosurfaktan Isolat Bakteri}

Sebelum mengukur produksi biosurfaktan yang dihasilkan oleh isolat bakteri terlebih dahulu dibuat standar biosurfaktan dengan menggunakan rhamnosa murni. Larutan rhamnosa dibuat dengan konsentrasi bervariasi (10, 50, 100 dan 200 ppm) kemudian diukur absorbansinya pada panjang gelombang $421 \mathrm{~nm}$. Persamaan garis regresi kurva standar rhamnosa ditentukan dengan metode Least Square. Produksi biosurfaktan yang dihasilkan dianalisis dengan metode orsinol yang dimodifikasi [10], [11]. Isolat bakteri yang dikultur di media BHB selama 14 hari disentrifugasi dengan kecepatan 6000 rpm selama 10 menit. Supernatan diekstrak dengan larutan eter. Lapisan eter yang terbentuk diambil dan dikeringkan kemudian dilarutkan kembali dalam $2 \mathrm{ml}$ larutan sodium bikarbonat $\left(\mathrm{NaHCO}_{3}\right) 0,05 \mathrm{M}$, lalu ditambahkan $3,6 \mathrm{ml}$ larutan orsinol, dipanaskan hingga mendidih, didinginkan pada suhu ruang lalu diukur absorbansinya dengan menggunakan spektrofotometer UV-VIS pada panjang gelombang 421 $\mathrm{nm}$.

\section{HASIL DAN PEMBASAN}

Dari hasil isolasi, diperoleh 9 isolat bakteri yang mampu tumbuh pada media BHA. Dari karakterisasi pewarnaan Gram 2 isolat Gram positif dan 7 isolat Gram negatif. Karakterisasi morfologi dan warna koloni masing-masing isolat menunjukkan variasi yang berbeda-beda. Karakterisasi morfologi dan sel isolat bakteri ditunjukkan pada Tabel 1.

Beberapa penelitian menunjukkan bakteri penghasil biosurfaktan dapat diisolsi dari lingkungan yang tercemar seperti tanah yang terkontaminasi minyak memiliki karakteristik yang berbeda-beda. Satu dari empat puluh dua isolat bakteri yang paling potensial yaitu isolat BS-3 merupakan Gram negatif [12]. Bakteri penghasil biosurfaktan juga berhasil diisolasi dari laut yang terkontaminasi minyak di Sumatera Utara yaitu sebanyak 13 isolat, 3 isolat Gram positif dan 9 isolat Gram negatif [10]. 16 Isolat bakteri penghasil biosurfaktan juga berhasil diisolasi dari tanah yang tercemar Pestisida di daerah pertanian Berastagi yang didominasi oleh bakteri Gram negatif [2].

Karakterisasi biokimia menunjukkan bahwa seluruh isolat memiliki karakteristik yang berbeda. Karakteristik biokimia isolat bakteri ditampilkan pada Tabel 2. Karakterisasi mikrob seperti morfologi isolat merupakan salah satu hal yang sangat penting untuk identifikasi. Morfologi mikroorganisme berdasarkan bentuk, ukuran dan penataan biasanya tidak cukup untuk melakukan identifikasi. Ciri lain seperti sifat pewarnaan, pola pertumbuhan koloni, reaksi pertumbuhan pada karbohidrat, dan penggunaan asam amino sangat membantu dalam identifikasi mikrob [13].

Hasil pengukuran volume emulsi biosurfaktan dari 9 isolat bakteri memiliki aktivitas biosurfaktan yang berbeda-beda. Biosurfaktan yang diproduksi oleh masing-masing isolat bakteri memiliki konsentrasi yang berbeda-beda juga. Aktivitas dan konsentrasi biosurfaktan ditunjukkan pada Tabel 3. Aktivitas pembentukan emulsi tertinggi ditunjukkan oleh isolat FB6 $(5,627 \mathrm{ml})$ dan terendah ditunjukkan oleh isolat FB1 (2,582 ml). 
Tabel 1. Karakterisasi morfologi koloni dan sel isolat bakteri.

\begin{tabular}{|c|c|c|c|c|c|c|c|}
\hline \multirow{2}{*}{ Isolat } & \multicolumn{4}{|c|}{ Morfologi koloni } & \multirow{2}{*}{ Gram } & \multicolumn{2}{|c|}{ Morfologi Sel } \\
\hline & Bentuk & Tepi & Elevasi & Warna & & Bentuk & Penataan \\
\hline FB1 & Tidak beraturan & Berombak & Datar & Putih & - & Kokus & Mono \\
\hline FB2 & Tidak beraturan & Rata & Datar & Kuning & - & Kokus & Diplo \\
\hline FB3 & Bulat & Rata & Cembung & Kuning & - & Kokus & Diplo \\
\hline FB4 & Tidak beraturan & Berombak & Cembung & Putih & - & Basil & Mono \\
\hline FB5 & Bulat & Rata & Cembung & Kuning & + & Kokus & Mono \\
\hline FB6 & Bulat & Rata & Cembung & Krem & - & Basil & Mono \\
\hline FB7 & Tidak beraturan & Berbelah & Cembung & Kuning & - & Kokus & Mono \\
\hline FB8 & Tidak beraturan & Berombak & Cembung & Krem & + & Basil & Mono \\
\hline FB9 & Tidak beraturan & Berombak & Cembung & Krem & - & Basil & Mono \\
\hline
\end{tabular}

Tabel 2. Karakteristik biokimia sel bakteri

\begin{tabular}{|c|c|c|c|c|c|c|}
\hline \multirow{2}{*}{ Isolat } & \multicolumn{6}{|c|}{ Uji Biokimia } \\
\hline & TSIA & Sitrat & Amilase & Katalase & Gelatin & Motilitas \\
\hline FB1 & + & - & - & + & + & + \\
\hline FB2 & + & + & - & + & + & + \\
\hline FB3 & + & - & - & - & + & + \\
\hline FB4 & + & - & + & + & + & + \\
\hline FB5 & + & + & + & + & - & + \\
\hline FB6 & + & - & - & + & + & + \\
\hline FB7 & + & - & - & + & + & + \\
\hline FB8 & + & - & + & + & - & + \\
\hline FB9 & + & - & + & + & + & + \\
\hline
\end{tabular}

Biosurfaktan memiliki gugus hidrofilik dan hidrofobik dengan adanya kedua gugus tersebut mempermudah bakteri mengemulsi senyawa yang tidak larut di dalam air [14]. Tingginya aktivutas biosurfaktan yang dihasilkan bakteri dapat disebabkan oleh beberapa faktor yaitu jenis sumber karbon, $\mathrm{pH}$, suhu dan salinitas yang digunakan. Aktivitas biosurfaktan menurun saat $\mathrm{pH}$ diturunkan menjadi asam sehingga terjadi presipitasi [15].

Dari hasil pengukuran konsentrasi biosurfaktan, konsentrasi tertinggi ditunjukkan oleh isolat FB7 (54,6 $\mathrm{ppm})$ dan terendah isolat FB8 (1,00 ppm). Isolat FB7 mampu memproduksi biosurfaktan paling tinggi kemungkinan disebabkan oleh faktor lingkungan seperti suhu dan $\mathrm{pH}$ media yang diberikan sesuai dengan kondisi optimum isolat FB7 untuk memproduksi biosurfaktan. Faktor lingkungan seperti suhu dan $\mathrm{pH}$ maupun keberadaan oksigen mempengaruhi produksi biosurfaktan [7]. Produksi biosurfaktan oleh bakteri Pseudomonas sp. meningkat pada suhu $37^{\circ} \mathrm{C}$ dan $\mathrm{pH} 7$. Biosurfaktan yang dihasilkan oleh bakteri ada yang diekskresikan langsung ke media atau hanya diekskresikan pada permukaan selnya saja [16].

Tabel 3. Aktivitas biosurfaktan dan konsentrasi biosurfaktan dari isolat bakteri

\begin{tabular}{lcc}
\hline $\begin{array}{c}\text { Isolat } \\
\text { bakteri }\end{array}$ & Volume emulsi (mL) & $\begin{array}{c}\text { Konsentrasi } \\
\text { biosurfaktan }(\mathrm{ppm})\end{array}$ \\
\hline FB1 & 2,582 & 10,4 \\
FB2 & 3,824 & 12,8 \\
FB3 & 4,019 & 21,6 \\
FB4 & 5,273 & 11,8 \\
FB5 & 4,494 & 25,8 \\
FB6 & 5,627 & 16,6 \\
FB7 & 3,881 & 54,6 \\
FB8 & 4,828 & 1 \\
FB9 & 4,474 & 6,4 \\
\hline
\end{tabular}

\section{SIMPULAN}

Hasil isolasi bakteri dari laut Belawan, Sumatera Utara diperoleh 9 isolat bakteri dengan karakteristik morfologi koloni dan sel yang berbeda. Isolat FB6 memiliki aktivitas biosurfaktan tertinggi dan FB7 memiliki konsentrasi biosurfaktan tertinggi.

\section{UCAPAN TERIMA KASIH}

Ucapan terima kasih kepada asisten laboratorium mikrobiologi FMIPA USU yang telah membantu penelitian ini.

\section{REFERENSI}

[1] A. Arif, "Pengaruh Bahan Kimia Terhadap Penggunaan Pestisida Lingkungan," J. Chem. Inf. Model., vol. 53, no. 9, pp. 1689-1699, 2013

[2] N. S. Damanik, "Isolasi dan Uji Potensi Bakteri Tanah Pertanian Berastagi Sumatera Utara dalam Mendegradasi Insektisida Marshal Berbahan Aktif Karbosulfan," Universitas Sumatera Utara, 2013.

[3] D. J. Puspita and Khaeruddin, "Kajian Bioremediasi Pada Tanah Tercemar Pestisida," Kovalen, vol. 2, no. 3, pp. 98106, 2016.

[4] T. H. Kurniati, I. Rusmana, A. Suryani, and N. R. Mubarik, "Degradation of Polycyclic Aromatic Hydrocarbon Pyrene by Biosurfactant-Producing Bacteria Gordonia cholesterolivorans AMP 10," Biosaintifika J. Biol. Biol. Educ., vol. 8, no. 3, p. 336, 2016.

[5] R. Tecon and J. R. Van Der Meer, "Effect of two types of biosurfactants on phenanthrene availability to the bacterial bioreporter Burkholderia sartisoli strain RP037," Appl. Microbiol. Biotechnol., vol. 85, no. 4, pp. 1131-1139, 2010.

[6] S. Shekhar, A. Sundaramanickam, and T. Balasubramanian, "Biosurfactant producing microbes and 
their potential applications: A review," Crit. Rev. Environ. Sci. Technol., vol. 45, no. 14, pp. 1522-1554, 2015.

[7] R. Batool, S. Ayub, and I. Akbar, "Isolation of biosurfactant producing bacteria from petroleum contaminated sites and their characterization," Soil Environ., vol. 36, no. 1, pp. 35-44, 2017.

[8] Y. Yunita, "Potensi Bakteri Penghasil Biosurfaktan Asal Laut Belawan Sumatera utara dalam mendegradasi Glifosat," Universitas Sumatera Utara, 2012.

[9] D. K. Jain, D. L. Collins-Thompson, H. Lee, and J. T. Trevors, "A drop-collapsing test for screening surfactantproducing microorganisms," J. Microbiol. Methods, vol. 13, no. 4, pp. 271-279, 1991.

[10] N. Priyani, E. Munir, I. W. Panjaitan, and K. Warsito, "the Potency of Local Isolates From North Sumatera in the Degradation of Naphtalene," in The 3rd International Conference on Biological Science 2013, 2015, vol. 2, no. 1, pp. 466-471.

[11] D. Utami, N. Priyani, and E. Munir, "Isolasi Dan Uji Potensi Bakteri Tanah Pertanian Berastagi Sumatera Utara
Dalam Mendegradasi Fungisida Antracol Berbahan Aktif Propineb," Saintia Biol., vol. 1, no. 2, pp. 8-14, 2013.

[12] T. Budsabun, "Isolation of Biosurfactant Producing Bacteria from Petroleum Contaminated Terrestrial Samples that Collected in Bangkok, Thailand," Procedia Soc. Behav. Sci., vol. 197, no. February, pp. 1363-1366, 2015.

[13] B. Lay, Analisis Mikroba di Laboratorium. Jakarta: PT. Radja Grafindo Perkasa, 1994.

[14] M. Pacwa-Płociniczak, G. A. Płaza, Z. Piotrowska-Seget, and S. S. Cameotra, "Environmental applications of biosurfactants: Recent advances," Int. J. Mol. Sci., vol. 12, no. 1, pp. 633-654, 2011.

[15] A. M. Elazzazy, "Isolation and characterization of biosurfactant production under extreme environmental conditions by alkali-halo-thermophilic bacteria from Saudi Arabia," Saudi J. Biol. Sci., vol. 22, no. 4, pp. 466475,2015

[16] K. K. Gautam and V. K. Tyagi, "Microbial Surfactants: A Review," J. Oleo Sci., vol. 55, no. 4, pp. 155-166, 2006. 